\title{
The ferric aerobactin receptor IutA, a protein isolated on agarose column, is not essential for uropathogenic Escherichia coli infection ${ }^{1}$
}

\author{
Taise Natali Landgraf ${ }^{2}$ \\ Alan Berlese ${ }^{3}$ \\ Fabricio Freitas Fernandes ${ }^{4}$ \\ Mariani Lima Milanezi ${ }^{5}$ \\ Roberto Martinez ${ }^{6}$ \\ Ademilson Panunto-Castelo ${ }^{7}$
}

\begin{abstract}
Although many proteins have been described involved in Escherichia coli colonization and infection, only few reports have shown lectins as important components in these processes. Because the mechanisms underlying $E$. coli colonization process involving lectins are not fully understood, we sought to identify the presence of other non-described lectins in $E$. coli. Here, we isolated a 75-kDa protein from E. coli on Sepharose column and identified it as ferric aerobactin receptor (IutA). Since IutA is controversially associated with virulence of some $E$. coli strains, mainly in uropathogenic $E$. coli (UPEC), we evaluated the presence of iutA gene in UPEC isolated from patients with urinary infection. This gene was present in only $38 \%$ of the isolates, suggesting a weak association with virulence. Because there is a redundancy in the siderophore-mediated uptake systems, we suggest that IutA can be advantageous but not essential for UPEC.
\end{abstract}

Descriptors: Uropathogenic Escherichia coli; Siderophores; Virulence.

\footnotetext{
${ }^{1}$ Supported by FAPESP (grant 06/04482-6)

2 Master's students, Faculdade de Medicina de Ribeirão Preto, Universidade de São Paulo, Brazil. Scholarship holder of the Scientific Initiation, FAPESP.

${ }^{3}$ Master's students, Faculdade de Medicina de Ribeirão Preto, Universidade de São Paulo, Brazil. Scholarship holder of M.Sc., FAPESP.

${ }^{4}$ Doctoral student, Faculdade de Medicina de Ribeirão Preto, Universidade de São Paulo, Brazil.

${ }^{5}$ Master's students, Faculdade de Medicina de Ribeirão Preto, Universidade de São Paulo, Brazil. Scholarship holder of Technical Training, FAPESP.

${ }^{6} \mathrm{PhD}$, Associate Professor, Faculdade de Medicina de Ribeirão Preto, Universidade de São Paulo, Brazil.

7 PhD, Professor, Faculdade de Filosofia, Ciências e Letras de Ribeirão Preto, Universidade de São Paulo, Brazil.
} 
O receptor de aerobactina IutA, uma proteína isolada em coluna de agarose, não é essencial para a infecção por Escherichia coli uropatogênica

Apenas alguns relatos na literatura demonstram que lectinas são importantes nos processos de colonização e infecção por Escherichia coli. A falta de compreensão clara dos mecanismos envolvendo lectinas, no processo de colonização por $E$. coli, motivou a realização deste estudo para se identificar a presença de outras lectinas não descritas em $E$. coli. Neste trabalho, isolou-se uma proteína de $75 \mathrm{kDa}$ de $E$. coli em coluna de Sepharose, correspondente ao receptor de aerobactina férrica (IutA). A associação de IutA com virulência de cepas de $E$. coli é controversa, principalmente em $E$. coli uropatogênica (UPEC), o que levou a se avaliar a presença do gene iutA em UPECs isoladas de pacientes com infecção urinária. O gene estava presente em $38 \%$ dos isolados, sugerindo fraca associação com virulência. Devido à existência de redundância nos sistemas de captura de ferro, sugere-se, aqui, que IutA possa ser vantajosa, mas não essencial para UPEC.

Descritores: Escherichia coli Uropatogênica; Sideróforos; Virulência.

\section{EI receptor de aerobactina IutA, una proteína aislada en columna de agarosa, no es esencial para la infección por Escherichia coli uropatógena}

La falta de una clara comprensión de los mecanismos de participación de las lectinas en el proceso de colonización por Escherichia coli, nos motivó a identificar la presencia de otras lectinas que no han sido descritas en $E$. coli. En este estudio, se aisló una proteína de $75 \mathrm{kDa}$ de $E$. coli en una columna de Sepharosa, correspondiente al receptor de aerobactina (IutA). La asociación de IutA con cepas virulentas de $\mathrm{E}$ coli es controvertido, especialmente en $E$. coli uropatógena (UPEC), lo que nos llevó a evaluar la presencia del gen iutA en UPECs aisladas de pacientes con infección urinaria. El gen estaba presente en $38 \%$ de los aislamientos, lo que sugiere una débil asociación con la virulencia. Debido a la existencia de redundancia en los sistemas de captura de hierro, se sugiere que IutA puede ser una ventaja, sin embargo no es esencial para la UPEC.

Descriptores: Escherichia coli Uropatogénica; Sideróforos; Virulencia.

\section{Introduction}

The intestinal microbiota of mammals includes several species of bacteria(1), which generally establish a relationship of mutualism with the host. The first step in the process of colonization of a host is the attachment of the colonizing agent on the epithelium of the colonized organism(2). In Gram-negative bacteria, a wide variety of molecules or structures can function as adhesins, which promote better adhesion to the epithelial cell receptor(3).

E. coli is the most abundant of all microorganisms that colonize the gut of many animals, and rarely causes disease except in immunocompromised hosts or when the gastrointestinal barriers are broken. The role of adhesins and lectins in the symbiosis of $E$. coli with the host is not well known, in contrast to pathogenic $E$. coli, which has some fimbriae associated with virulence. After the pioneer work ${ }^{(4)}$ that obtained the first direct evidence that $E$. coli contains lectin, some authors demonstrated that proteins with lectin property, such as type 1 and $P$ frimbriae, were determinant virulence factors important to the process of colonization and infection, especially of the bladder epithelium. The type 1 fimbria is one of the 
most studied virulence factor of $E$. coli, present in $80 \%$ of UPEC strains ${ }^{(5)}$. Besides type 1 and $P$ fimbriae, F17 fimbria was described as important to the pathogenesis of enterotoxigenic $E$. coli in ruminants(6).

Since lectins have shown to be such important components in the colonization and infection processes by bacteria and because some mechanisms underlying E. coli virulence are not fully understood, we sought to identify other non-described lectins as molecular markers.

Molecular markers from pathogens have been useful to hasten diagnosis, prevention and treatment for many infectious diseases. In urinary tract infection (UTI), studies using molecular methods have shown to be essential to understand the epidemiology, because the background rate of UTI is so high, and many different organisms can be the ethiological agent of these infections. Furthermore, the bacteria that most commonly cause UTI are E. coli strains( ${ }^{(7)}$, which comprise an extremely heterogeneous group ${ }^{(8)}$. UTI is a public health problem that requires the development of an effective treatment for prevention ${ }^{(9)}$. So, an understanding of the principles that guide such studies about molecular markers is essential for nurses in all areas of clinical practice, since these professionals are responsible for the planning, assessment and implementation of such strategies, leading to more effective assistance for patients and community.

In this work, we identified an agarose-binding protein of $75-\mathrm{kDa}$ in $E$. coli as a candidate for a new protein with lectin-activity, with a putative role in $E$. coli virulence. This protein was identified as the precursor of the ferric aerobactin receptor (IutA), a siderophore receptor encoded by a gene from the plasmid pColV-30(10), which is associated with virulence of some E. coli strains ${ }^{(11)}$. We also evaluated the presence of iutA gene in UPEC strains to correlate with bacterial infection.

\section{Methods}

\section{Isolation of carbohydrate-binding protein from E. coli}

UPEC isolate (kindly provided by Dr. Ebert Hanna, Invent Biotecnologia Ltda, Ribeirão Preto, Brazil) was cultured in Dulbecco's modified Eagle medium (DMEM)(12) in house at $37^{\circ} \mathrm{C}$, shaking at $200 \mathrm{rpm}$ overnight. In order to evaluate the influence of ions in the production of bacterial proteins, the DMEM was supplemented with 22 $\mathrm{mM} \mathrm{KH} \mathrm{PO}_{4}, 10 \mathrm{mM} \mathrm{CaCl}{ }_{2}, 0.25 \mathrm{mM} \mathrm{Fe}\left(\mathrm{NO}_{3}\right)_{3}$ or $22 \mathrm{mM}$
$\mathrm{KH}_{2} \mathrm{PO}_{4}$ plus $0.25 \mathrm{mM} \mathrm{Fe}\left(\mathrm{NO}_{3}\right)_{3}{ }^{(12)}$. Cells were harvested by centrifugation $\left(10,000 \times \mathrm{g}\right.$ for 15 minutes at $\left.4^{\circ} \mathrm{C}\right)$, resuspended in $25 \mathrm{~mL}$ of TBS-azide (Tris-buffered saline solution containing $10 \mathrm{mM} \mathrm{CaCl}, 2 \%(\mathrm{v} / \mathrm{v})$ Triton X-100 and $0.02 \%(\mathrm{~m} / \mathrm{v})$ sodium azide, $100 \mathrm{mM}$ MOPS, $\mathrm{pH} 7.4$ ) and sonicated on ice with 5 pulses of 30 seconds each, $60 \mathrm{~Hz}$ (Vibra-cell, Sonics \& Materials Inc., Danbury, USA). Bacterial lysates were centrifuged at $10,000 \times$ $\mathrm{g}$ for 15 minutes at $4^{\circ} \mathrm{C}$. The lysate supernatants were submitted to two processes: a. serial incubation with Sepharose CL-4B and carbohydrate-immobilized beads (d-galactose, d-mannose, $d$-GlcNAc and lactose) for 1 hour at room temperature. After washing the beads with TBS to remove non-absorbed material, the beads were submitted to SDS-PAGE. b. Affinity chromatography on column of Sepharose CL-4B, bed volume of $1 \mathrm{~mL}$, by using ÄKTA Purifier System (GE Healthcare Life Sciences, Uppsala, Sweden). The material adsorbed to the column was eluted with $1 \mathrm{M} \mathrm{NaCl}$ or $0.1 \%$ acetic acid. Chromatography was monitored by absorbance at $280 \mathrm{~nm}$ and the eluted fractions were collected in pools, concentrated and dialyzed against TBS, using Amicon centrifugal filters Ultra-15 (membrane exclusion size of $10-\mathrm{kDa}$ ) (Millipore, Billerica, USA), according to manufacturer instructions. Concentrated eluates were resolved on $10 \%$ sodium dodecyl sulfate-polyacrylamide gel (SDS-PAGE) and the gels were stained with Coomassie blue.

\section{Identification of proteins}

Coomassie blue-stained proteins were excised and trypsinized in the gel prior to analysis by $1 \mathrm{D}$ nLC-MSMS, using a 4000 QTrap (Applied Biosystems) tandem MS system (Fingerprints Proteomics Facility, University of Dundee). The raw QTrap data were analyzed using Mascot (www.matrixscience.com).

\section{Polymerase chain reaction (PCR) of iutA gene in UPEC strains}

UPEC strains, which were isolated from urine of hospitalized patients, were collected in the Emergency Unit of the University Hospital of the Faculty of Medicine of Ribeirão Preto, University of São Paulo, in the period from July to September 2009. These strains were submitted to PCR to detect iutA gene. The plasmid pPOC9-iutA, kindly provided by Dr. Michael O'Connell, Dublin City University, Ireland(13), was used as positive control. The PCR assays was carried out with $20 \mu \mathrm{L}$ of 
reaction mixture, containing 1 colony of each tested strain, $1,25 \mu \mathrm{M}$ of the primers $5^{\prime}$-AAATTCCATATGATG ATAAGCAAAAAG-3' and 5'-TTCAAGCTTTCAGAACAGCA CAGAGTAG-3', $0.2 \mathrm{mM}$ of each deoxynucleoside triphosphate, 10X PCR buffer, $1.5 \mathrm{mM} \mathrm{MgCl}_{2}, 2 \mathrm{U}$ of Taq DNA polymerase (Fermentas, Burlington, Canada), performed in an Eppendorf Master Cycler Gradient Thermocycler (Eppendorf Scientific, Inc., Westbury, USA), as follows: $94^{\circ} \mathrm{C}$ for $5 \mathrm{~min}, 30$ cycles at $94^{\circ} \mathrm{C}$ for 1 minute, $51^{\circ} \mathrm{C}$ for 1 minute and $72^{\circ} \mathrm{C}$ for 2.5 minutes and, at the end of these 30 cycles, $72^{\circ} \mathrm{C}$ for 5 minutes. Reactions were kept at $4^{\circ} \mathrm{C}$ until use. PCR products were analyzed on $1 \%$ agarose gel after ethidium bromide staining and the amplicons were identified based on the size of the amplified product.

This work was approved by the Ethics Committee of the College of Nursing of Ribeirão Preto, University of São Paulo, protocol 0737/2006.

\section{Results}

\section{E. coli presents an agarose-binding 75-KDa protein}

To identify carbohydrate-binding proteins that could be specific for colonization we first cultured $E$. coli in minimum medium (DMEM) that mimics the gastrointestinal tract conditions ${ }^{(12)}$. When the supernatant lysate from $E$. coli was serially incubated with Sepharose CL-4B and carbohydrate-immobilized resins, we did not detect adsorbed proteins to Sepharose (Figure 1A, lane 1) or carbohydrate-immobilized resins (data not shown). Based on the work of Kenny et al. ${ }^{(12)}$, who obtained an increase in the production of virulence factors of EPEC when the minimum medium was supplemented with salts, we cultured bacteria in DMEM, supplemented with $22 \mathrm{mM} \mathrm{KH}_{2} \mathrm{PO}_{4}, 10 \mathrm{mM} \mathrm{CaCl}, 0.25 \mathrm{mM} \mathrm{Fe}\left(\mathrm{NO}_{3}\right)_{3}$ or $22 \mathrm{mM} \mathrm{KH}_{2} \mathrm{PO}_{4}$ plus $0.25 \mathrm{mM} \mathrm{Fe}\left(\mathrm{NO}_{3}\right)_{3}$. The induction of Sepharose-binding proteins was observed only in bacteria grown in DMEM supplemented with $\mathrm{CaCl}_{2}$ (Figure 1A, lane 3 ). In the preparation, we obtained a major protein of $75-\mathrm{kDa}$, followed by minor proteins of $>97-\mathrm{kDa}, \sim 85-\mathrm{kDa}$ and a duplex of $\sim 40-\mathrm{kDa}$. Because agarose is a support to immobilize carbohydrate, we first incubated the lisate with Sepharose CL-4B, followed by others resins. Because the $75-\mathrm{kDa}$ protein bound Sepharose CL-4B, we were not able to detect proteins in other resins.
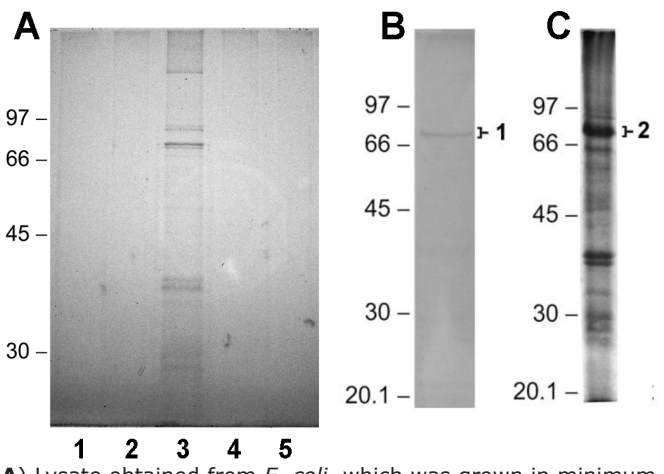

(A) Lysate obtained from $E$. coli, which was grown in minimum medium (1) without additional supplementation with salts or supplemented with (2) $\mathrm{KH}_{2} \mathrm{PO}_{4}$ (3) $\mathrm{CaCl}_{2}$, (4) $\mathrm{Fe}\left(\mathrm{NO}_{3}\right)_{3}$, (5) $\mathrm{KH}_{2} \mathrm{PO}_{4}$ and $\mathrm{Fe}\left(\mathrm{NO}_{3}\right)_{3}$, was incubated with Sepharose CL-4B. After washing, the beads containing adsorbed proteins were submitted to SDS-PAGE. Lysate from $E$. coli grown in minimum medium supplemented with $\mathrm{CaCl}_{2}$ was also submitted to affinity chromatography on Sepharose. Adsorbed material was eluted with (B) $1 \mathrm{M} \mathrm{NaCl}$ and (C) $0.1 \%$ acetic acid, dialyzed and submitted to SDS-PAGE. Gels were stained with Coomassie Blue. Migration positions of molecular mass markers are shown on the left in $\mathrm{kDa}$.

Figure 1 - Protein of 75-kDa from UPEC binds to Sepharose CL-4B in a manner dependent on $\mathrm{Ca}^{+}$

\section{Protein of 75-kDa correspond to lutA from E. coli}

The $75-\mathrm{kDa}$ proteins from $E$. coli obtained by affinity chromatography on Sepharose column, eluted with $1 \mathrm{M} \mathrm{NaCl}$ and $0.1 \%$ acetic acid, were submitted to electrophoresis (Figure $1 \mathrm{~B}$ and $\mathrm{C}$, respectively) and to identification by MS. The tryptic peptides of the 75kDa protein showed high identity with protein involved in iron uptake by bacteria, IutA.

\section{Detection of iutA gene in UPEC strains}

Since IutA is expressed in conditions that mimic the site of $E$. coli colonization and has been associated with virulence ${ }^{(11)}$, we sought to determine the presence of the iutA gene in $E$. coli strains and correlated to bacterial infection. To detect the iutA gene in UPEC strains, initially, we performed an amplification reaction in an iutA-subcloned plasmid (pPOC9-iutA). As shown in Figure 2, lane + , amplified product had a size between 2,322 and 2,027 bp, consistent with the expected size of 2,202 bp for iutA gene. The pPoc9-iutA was used as positive control (Figure 2, lane + ) in all reactions.

The gene was detected in 14 out of 37 UPEC isolates (data not shown). To confirm the amplifications, positive isolates were submitted to another amplification reaction (Figure 2). Though the samples of lanes 5 and 6 had a weak amplification, we validated that 14 UPEC isolates 
contained iutA gene, accounting for $38 \%$ positivity among UPECs. There was no association between the positivity of IutA in UPEC and severity of infections (data not shown), making us question whether IutA is really a virulence factor of $E$. coli.

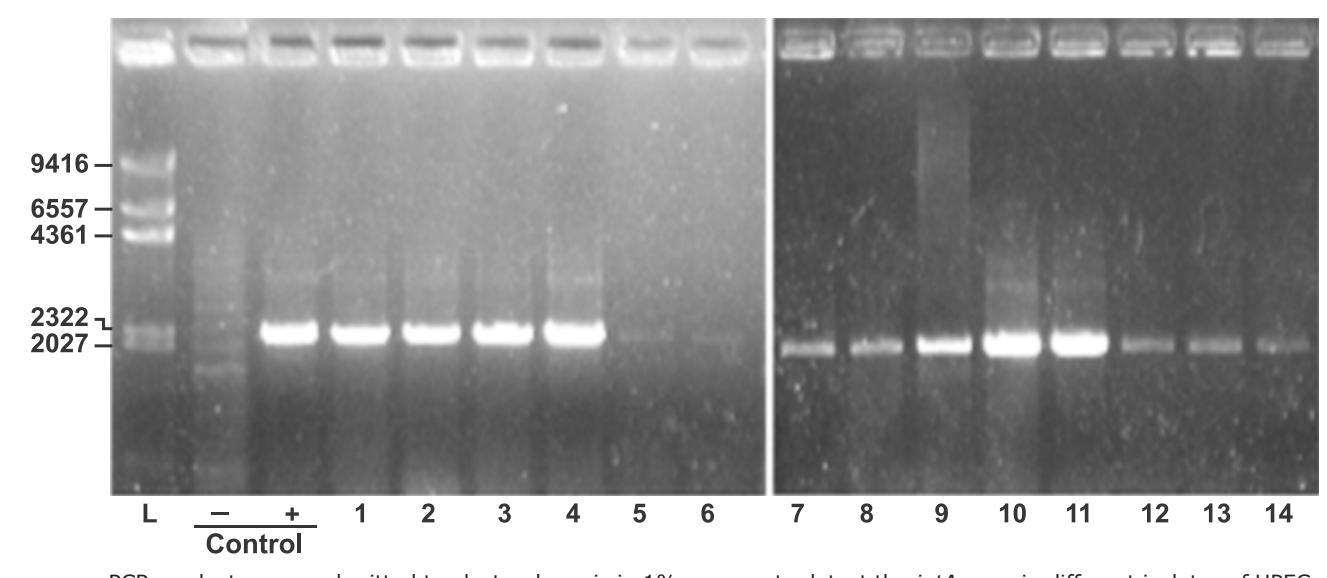

PCR products were submitted to electrophoresis in $1 \%$ agarose to detect the iutA gene in different isolates of UPEC. (L) $1 \mathrm{kbp}$ DNA ladder, (-) negative control, (+) positive control and (1-14) UPEC isolates. Gels were stained with ethidium bromide. Migration positions of DNA ladder segments are indicated on the left in bp

Figure 2 - Detection of iutA gene in UPEC strains

\section{Discussion}

Up to date, only a few carbohydrate-binding proteins have been identified in E. coli. Moreover, their role in protein-carbohydrate interaction mediated bacterial colonization is scarcely known ${ }^{(6)}$. Therefore, we attempted to identify new carbohydrate-binding proteins that could be involved in E. coli colonization. Here, we report the isolation and identification of a protein of 75-kDa as the ferric aerobactin receptor (IutA), which appears to have carbohydrate-binding property and to be important for colonization.

Interestingly, IutA was expressed only in E. coli grown in DMEM supplemented with calcium that mimics conditions found in the gut environment ${ }^{(12)}$. In addition, this protein was not produced by bacteria cultured in LB broth, even when supplemented with $\mathrm{CaCl}_{2}$ (data not shown), suggesting that additional environmental signals, such as nutritional stress, may be responsible for producing this protein.

The adsorption of $75-k D a$ protein to Sepharose was reproducible, even with the affinity chromatography on Sepharose column, which made us suggest that the protein is a ligand of galactose, since Sepharose is a polymer consisting of alternating residues of $\beta$-D-galactopyranose 3-O-linked and 3,6-anhydro$\alpha$-L-galactopyranose $4-O$-linked ${ }^{(14)}$. Although no 75 $\mathrm{kDa}$ protein has been eluted with $0.1 \mathrm{M}$ D-galactose or lactose from the column (data not shown), we hypothesized that a higher specificity of this protein by the disaccharide repeating units that compose the agarose and a low specificity by monosaccharide or disaccharide, as occurs with some plant lectins, avoided the elution of the protein. There is no doubt that this is one of the reasons why the classification of lectins according to monosaccharide specificity sometimes masks the strange characteristics these proteins often display for di, tri or tetrasaccharide, with association constants up to 1,000 times higher compared to monosaccharides. In addition, many times, the threedimensional conformation of the oligosaccharide provides complex structures that cannot be mimicked by simple sugars ${ }^{(15)}$. The identification of the 75-kDa protein from $E$. coli as IutA, which is a siderophore receptor to ferric aerobactin, was a interesting result, as this molecule involved in the capture of iron is involved in the colonization process and essential for bacterial growth in the host ${ }^{(10,16)}$. Siderophore and siderophore-mediated uptake systems play a crucial role in microbial virulence, since they are essential for bacterial pathogenesis. However, there is a redundancy of these systems, which makes it difficult to associate virulence with a specific siderophore receptor(17). Although IutA is expressed in pathogenic bacteria and frequently associated with virulence $^{(11)}$, we did not detect preferentially iutA gene among UPEC isolates, because only $38 \%$ of the UPEC isolates presented iutA gene. These findings corroborate a recent study ${ }^{(18)}$ that showed positivity only in $14 \%$ of urine isolates.

Several studies have demonstrated the mode of action of receptor-Fe siderophores, such as aerobactin receptor, but no mention has been made of the dependence on 
protein-carbohydrate interaction in this system. Though the glycosylation of proteins in bacteria is limited, other glycoconjugates are abundant ${ }^{(19)}$. These glycoconjugates could somehow interact with protein, like in organisms of higher complexity. Moreover, glycosylated siderophores have been found, such as salmochelin, although it is not clear why this modification occurs ${ }^{(20)}$.

\section{Conclusion}

The correlation between Sepharose-binding IutA and protein system for iron uptake of $E$. coli offers an interesting study of the participation of lectins in this process. The identification of novel carbohydratebinding proteins is an open field for many discoveries, as a possible involvement of these proteins in the tissue colonization process. In this study, we demonstrated that, although IutA might be important to the EPEC infection, it did not play an essential role in this process.

\section{Acknowledgements}

We thank Dr. Leandro L. Oliveira, Denissami A. S. F. Lima, Izaíra Brandão, Ana Paula Masson and Ana Flávia Gembre for technical assistance; Dr. Ebert Hanna from Invent Biotecnologia, Brazil, for providing commensal E.coli and Dr. Michael O'Connell from Dublin City University, Ireland, for the generous donation of plasmid pPoc9-iutA. We are grateful to Dr. Andrea Kaufmann Zeh for a critical review of the manuscript.

\section{References}

1. Xu J, Bjursell MK, Himrod J, Deng S, Carmichael LK, Chiang HC, et al. A genomic view of the humanBacteroides thetaiotaomicron symbiosis. Science. 2003;299(5615):2074-6.

2. Neish AS. The gut microflora and intestinal epithelial cells: a continuing dialogue. Microbes Infect. 2002;4(3):309-17.

3. Sharon $\mathrm{N}$, Lis H. History of lectins: from hemagglutinins to biological recognition molecules. Glycobiology. 2004;14(11):53R-62R.

4. Aronson M, Medalia O, Schori L, Mirelman D, Sharon

$\mathrm{N}$, Ofek I. Prevention of colonization of the urinary tract of mice with Escherichia coli by blocking of bacterial adherence with methyl alpha-D-mannopyranoside. J Infect Dis. $1979 ; 139(3): 329-32$.

5. Kucheria R, Dasgupta P, Sacks SH, Khan MS, Sheerin NS. Urinary tract infections: new insights into a common problem. Postgrad Med J. 2005;81:83-6.

6. Sharon N. Carbohydrates as future anti-adhesion drugs for infectious diseases. Biochim Biophys Acta. 2006;1760(4):527-37.
7. Hagan EC, Lloyd AL, Rasko DA, Faerber GJ, Mobley HL. Escherichia coli global gene expression in urine from women with urinary tract infection. PLoS Pathog. 2010;6(11):e1001187.

8. Foxman B, Riley L. Molecular epidemiology: focus on infection. Am J Epidemiol. 2001;153(12):1135-41.

9. Hagan EC, Mobley HL. Uropathogenic Escherichia coli outer membrane antigens expressed during urinary tract infection. Infect Immunol. 2007;75(8):3941-9.

10. Williams $\mathrm{PH}$. Novel iron uptake system specified by ColV plasmids: an important component in the virulence of invasive strains of Escherichia coli. Infect Immunol. 1979;26(3):925-32.

11. Crosa JH, Walsh CT. Genetics and assembly line enzymology of siderophore biosynthesis in bacteria. Microbiol Mol Biol Rev. 2002;66(2):223-49.

12. Kenny B, Abe A, Stein M, Finlay BB. Enteropathogenic Escherichia coli protein secretion is induced in response to conditions similar to those in the gastrointestinal tract. Infect Immunol. 1997;65(7):2606-12.

13. Cuiv $\mathrm{PO}$, Clarke $P, \mathrm{O}^{\prime}$ Connell $M$. Identification and characterization of an iron-regulated gene, chtA, required for the utilization of the xenosiderophores aerobactin, rhizobactin 1021 and schizokinen by Pseudomonas aeruginosa. Microbiology. 2006;152(Pt 4):945-54.

14. Hamer GK, Bhattacharjee SS, Yaphe W. Analysis of the enzymic hydrolysis products of agarose by $13 \mathrm{C}-\mathrm{n}$.m.r. spectroscopy. Carbohidr Res. 1977;54(1):C7-C10.

15. Lis $H$, Sharon N. Lectins: Carbohydrate-Specific Proteins That Mediate Cellular Recognition. Chem Rev. 1998;98(2):637-74.

16. Dho M, Lafont JP. Adhesive properties and iron uptake ability in Escherichia coli lethal and nonlethal for chicks. Avian Dis. 1984;28(4):1016-25.

17. Ratledge C, Dover LG. Iron metabolism in pathogenic bacteria. Annu Rev Microbiol. 2000;54:881-941.

18. Henderson JP, Crowley JR, Pinkner JS, Walker JN, Tsukayama P, Stamm WE, et al. Quantitative metabolomics reveals an epigenetic blueprint for iron acquisition in uropathogenic Escherichia coli. PLoS Pathog. 2009;5(2):e1000305.

19. Schmidt MA, Riley LW, Benz I. Sweet new world: glycoproteins in bacterial pathogens. Trends Microbiol. 2003;11(12):554-61.

20. Hantke K, Nicholson G, Rabsch W, Winkelmann G. Salmochelins, siderophores of Salmonella enterica and uropathogenic Escherichia coli strains, are recognized by the outer membrane receptor IroN. Proc Natl Acad Sci USA. $2003 ; 100(7): 3677-82$. 